\title{
Experimental research for obtaining functional ingredients from Jerusalem artichoke and hemp seeds
}

\author{
Iuliana Găgeanu ${ }^{1}$, Cătălin Persu ${ }^{1}$, Gabriel Gheorghe ${ }^{1}$, Diana Popa $^{2}$ and Liliana Dumitrescu ${ }^{3 *}$ \\ ${ }^{1}$ INMA Bucharest, Ion Ionescu de la Brad nr. 6, sector 1, Bucharest, Romania \\ ${ }^{2}$ Agricultural Research-Development Station Secuieni, 377 Principala, Secuieni, Romania \\ ${ }^{3}$ Hydraulics and Pneumatics Research Institute INOE 2000-IHP, 14, Cuțitul de Argint, Bucharest, \\ 040558, Romania
}

\begin{abstract}
Functional ingredients have gained a large-scale development determined by the increased interest shown by consumers worldwide. Functional ingredients are bioactive compounds that can be used in the manufacture of functional food products. These bioactive compounds can be obtained from accessible materials. The use of these materials aims to transform affordable raw materials at low prices into functional ingredients concentrated in proteins, amino acids, minerals and fibres, which can be used to obtain foods with a beneficial role in health. The paper presents a series of experimental researches for obtaining and characterizing functional materials obtained from Jerusalem artichoke and hemp seeds. The samples obtained had low moisture content, between $5.11-5.43 \%$ for Jerusalem artichoke and $4.8-5.13 \%$ for hemp, ideal for storage and use as powder. Jerusalem artichoke registered high sugar contents (between $21.2-27.2 \%$ ), while hemp flour had high fat content (between 18.56 - $23.52 \%$ ), making both products suitable to be used as functional ingredients in the food industry.
\end{abstract}

\section{Introduction}

Functional ingredients can be described as bioactive compounds that have the potential to beneficially influence health above the basic nutritional value of normal foods. Foods containing one or more functional ingredients (also called functional foods) can be defined as foods having health properties over and above their original nutritional value [ $1-5]$.

Bioactive compounds / functional ingredients can be obtained from a variety of sources (primary produce, marine sources, microorganisms, inorganic raw materials). They can also result as a by-product of food processing, bringing new economic value to food processors.

The use of these primary produce aims to transform cheap raw materials into functional ingredients concentrated in proteins, amino acids, minerals and fiber, which can be used to obtain foods with a beneficial role on health, due to a synergism between the density of nutrients and the presence dietary fiber with proven benefits in regulating cholesterol, regulating intestinal transit, increasing satiety and weight management, improving glucose

* Corresponding author: lilianad.ihp@fluidas.ro 
tolerance and insulin response, reducing hyperlipidaemia, hypertension and risk factors for coronary heart disease, reducing the risk of developing cancers [7-9].

In order to obtain functional ingredients, the materials used as raw materials must go through a conditioning stage, ensuring the maintenance of nutrients and all their qualities.

Cereal crops occupy more than half of crops in the world, grains being the main food item in agriculture [10]. Hemp has been used from ancient times both for its fiber, and also for its nutritional benefits. Jerusalem artichoke has been widely used both for its biomass potential (used for obtaining biofuels) and for its food potential, its inulin content having benefits in diabetes diets [10-19].

The food supplement obtained from these two types of plants contribute both to the secretion of gastric juices and to the increase of the capacity to contract the intestinal walls (thus stimulating the intestinal peristalsis).

In addition, bioactive compounds separated by supercritical extraction at normal temperature $\left(30-35{ }^{\circ} \mathrm{C}\right.$ ) from hemp cakes and Jerusalem artichoke may contribute to the binding (in the form of insoluble compounds) to substances harmful to the body (free radicals, heavy metals, radionuclides) thus contributing to their elimination, regulating blood composition (especially the number of red blood cells and leukocytes) and improving liver function [20-22].

Cakes resulting from the processing (cold pressing) of hemp seeds and Jerusalem artichoke flour can be used to create food supplements ennobled with natural antioxidants, which contribute to the normalization of lipid and carbohydrate metabolism, and to maintain the intestinal flora in optimal conditions.

The paper presents a series of experiments for the preliminary processing of Jerusalem artichoke and hemp cakes in the view as using them as functional ingredients and further obtaining by-products and dietary supplements.

\section{Material and method}

The materials used for obtaining functional ingredients were represented by three varieties of Jerusalem artichoke, grown within the premises of INMA Bucharest, Figure 1, and three cake samples from three varieties of hemp (resulted from the extraction of oil from seeds), Figure 2.

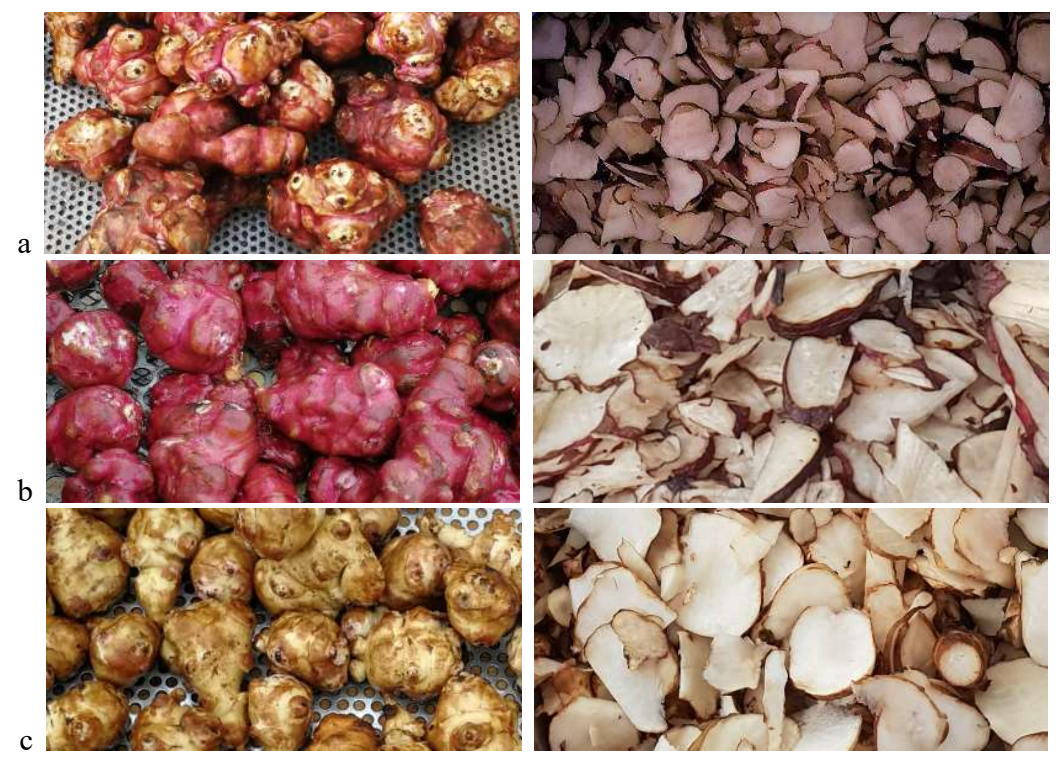

Fig. 1. Jerusalem artichoke samples used for the experimental research. a - Rareş variety; b - Dacic variety; c - Olimp variety 


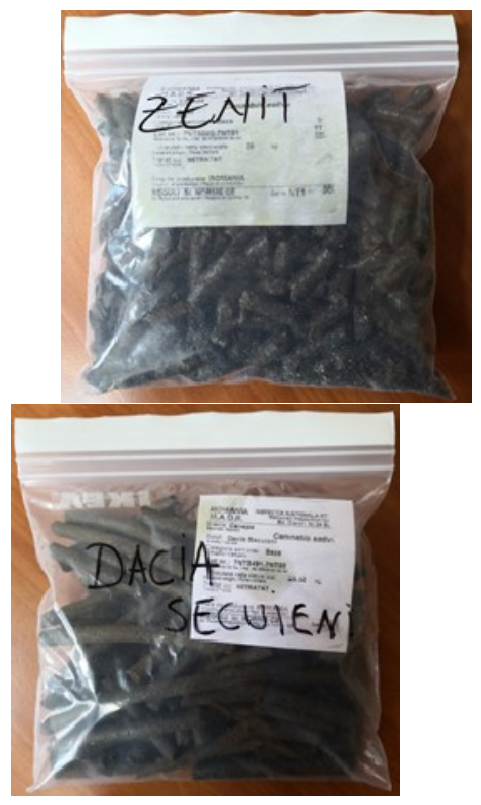

a

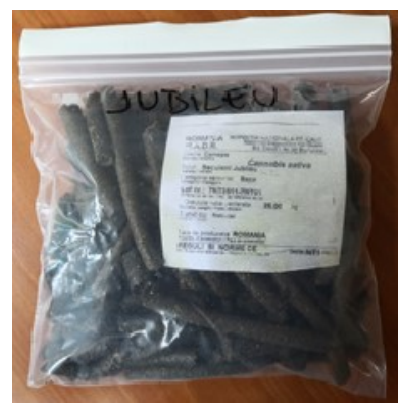

Fig. 2. Hemp samples used for the experimental research. a - Zenit variety; b - Jubileu variety; c Dacia Secuieni variety

Table 1. Initial samples used for experiments.

\begin{tabular}{|c|c|c|c|}
\hline $\begin{array}{l}\text { Sample } \\
\text { number }\end{array}$ & \multicolumn{2}{|c|}{ Variety } & $\begin{array}{c}\text { Sample weigh } \\
{[\mathrm{g}]}\end{array}$ \\
\hline 1 & \multirow{3}{*}{$\begin{array}{l}\text { Jerusalem } \\
\text { artichoke }\end{array}$} & Rareş & 5000 \\
\hline 2 & & Dacic & 5000 \\
\hline 3 & & Olimp & 5000 \\
\hline 4 & \multirow{3}{*}{ Hemp } & Zenit & 1000 \\
\hline 5 & & Jubileu & 1000 \\
\hline 6 & & $\begin{array}{l}\text { Dacia } \\
\text { Secuieni }\end{array}$ & 1000 \\
\hline
\end{tabular}

In order obtain functional ingredients, the materials had to first pass through a drying phase. The drying was achieved using a technical drying equipment (Figure 3 ). It is designed to act on the product, depending on the quality requirements imposed by the beneficiary, respectively on its physical characteristics, offering the possibility to dry samples at low temperatures, thus maintaining intact their properties.

The drying of all samples in the oven was done at $40{ }^{\circ} \mathrm{C}$ and the process was constantly monitored. 


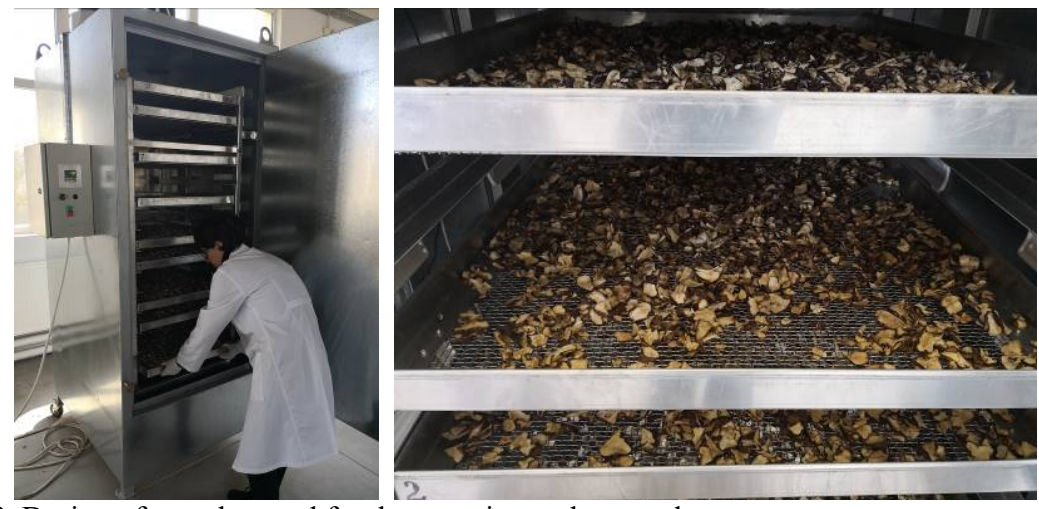

Fig. 3. Drying of samples used for the experimental research.

The grinding of samples was achieved using a mill for the fine grinding of dry food products. The granulation of the flour obtained varies depending on the orifice diameter of the sieve used. For the hemp and Jerusalem artichoke samples grinded was used a $2 \mathrm{~mm}$ orifice diameter sieve.
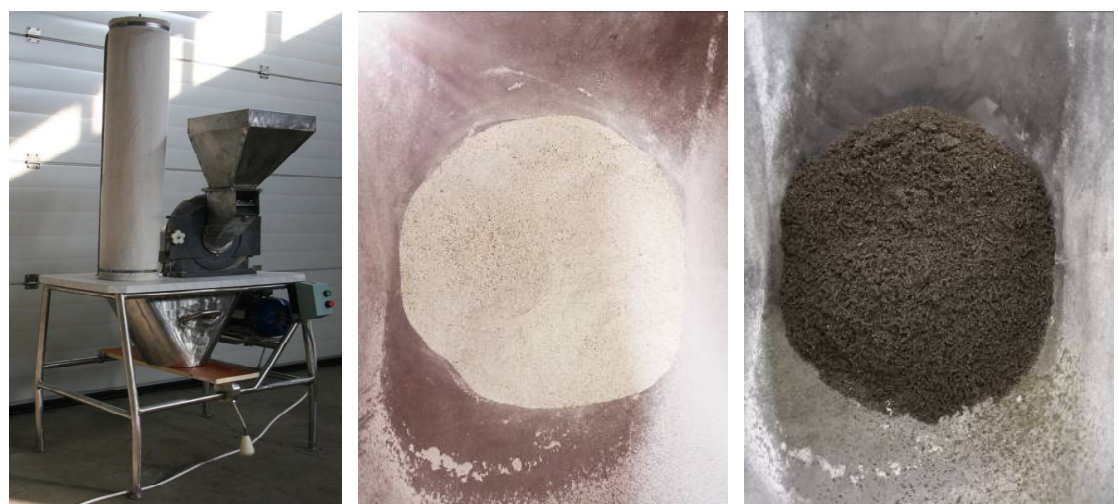

Fig. 4. Grinding of samples used for the experimental research.

The moisture of the samples before drying and after drying and grinding was determined by drying in an oven at $105^{\circ} \mathrm{C}$ and calculating the difference in mass,

The bulk density of the samples was determined by filling a stainless-steel cylinder of known volume and subsequently weighing the quantity in the cylinder.

For each sample of Jerusalem artichoke and hemp, before conditioning by drying and grinding, the percentage of fat was calculated using the Soxhlet method by extraction until depletion with organic solvents.

\section{Results}

The results obtained after dying the samples of Jerusalem artichoke and hemp seed cakes are presented in Table 2 .

Table 2. Results obtained after drying the samples

\begin{tabular}{|c|c|c|c|}
\hline $\begin{array}{c}\text { Sample } \\
\text { number }\end{array}$ & $\begin{array}{c}\text { Initial } \\
\text { moisture [\%] }\end{array}$ & $\begin{array}{c}\text { Weight after } \\
\text { drying [g] }\end{array}$ & $\begin{array}{c}\text { Moisture after } \\
\text { drying [\%] }\end{array}$ \\
\hline
\end{tabular}




\begin{tabular}{|c|c|c|c|}
\hline 1 & 73.41 & 1329 & 5.43 \\
\hline 2 & 66.95 & 1652 & 5.11 \\
\hline 3 & 75.46 & 1227 & 5.34 \\
\hline 4 & 15.27 & 907.9 & 5.13 \\
\hline 5 & 16.02 & 899.1 & 4.8 \\
\hline 6 & 15.18 & 904.2 & 5.21 \\
\hline
\end{tabular}

After grinding the samples, a series of tests were conducted, the results being presented in Table 3 and Figure 5.

Table 3. Results obtained after grinding samples

\begin{tabular}{|c|c|c|c|}
\hline $\begin{array}{c}\text { Sample } \\
\text { number }\end{array}$ & $\begin{array}{c}\text { Bulk } \\
\text { density } \\
{\left[\mathbf{k g} / \mathbf{m}^{3}\right]}\end{array}$ & $\begin{array}{c}\text { Fat content } \\
{[\mathbf{\%}]}\end{array}$ & $\begin{array}{c}\text { Sugar } \\
\text { content } \\
{[\%]}\end{array}$ \\
\hline 1 & 711.14 & - & 21.2 \\
\hline 2 & 726.87 & - & 26.4 \\
\hline 3 & 729.87 & - & 27.2 \\
\hline 4 & 815.33 & 18.56 & 1,52 \\
\hline 5 & 812.78 & 20.52 & 1,47 \\
\hline 6 & 894.14 & 23.52 & 1,51 \\
\hline
\end{tabular}

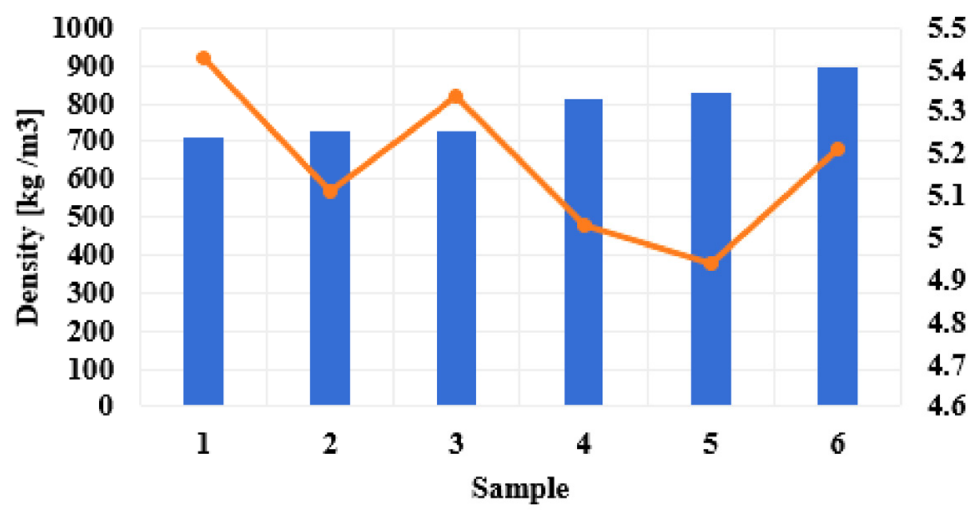

Density —-Moisture

Fig. 5. Variation of density with the moisture content for samples analyzed.

From the results in Tables 2 and 3 and Figure 5 it can observed that Jerusalem artichoke flour had a lower bulk density than hemp flour, mainly due to the high lipid content of 
hemp. All dried samples had moisture content close to 5\%, making them ideal for storage and use as dry ingredients.

\section{Conclusions}

Following the experiments of conditioning the Jerusalem artichoke samples in order to obtain functional ingredients that will be subsequently included in food products, the following conclusions can be drawn:

1. the moisture before drying had values between $66.95-75.46 \%$ for Jerusalem artichoke, the highest values being recorded for the Olimp variety, and between $15.18-16.02 \%$ for hemp, the highest values being recorded for Jubileu variety;

2. Following the drying process of samples, Jerusalem artichoke reached moistures between $5.11-5.43 \%$ and hemp between $4.59-5.13 \%$, ideal for storage in the view of future use;

3. Hemp samples retained a fat content between 18.56-20.52\% and a sugar content between $1.57-1.52 \%$, being indicated for consumption;

4. Jerusalem artichoke samples had a sugar content between $21.2-27.2 \%$, the high content making the samples valuable ingredients.

Acknowledgement: This work was supported by a grant from UEFISCDI, project "Complex system of integral capitalization of agricultural species with energy and food potential", code PN-III-P1-1.2PCCDI-2017-0566, Contract no. 9PCCDI /2018, P4 - Capitalizing on the food potential of selected agricultural crops (Jerusalem artichoke, sorghum seeds, cakes resulting from obtaining oil from coldpressed hemp seeds).

\section{References}

1. C.L. Kruger, S.W. Mann, Food and Chemical Toxicology J., 41, Issue 6, 793-805, (2003)

2. S. Cozzano, A. Fernández, M. D. del Castillo, A. Medrano Fernández, Ency. of Food Security and Sustain., 1, 351-359, (2019)

3. I. Ferreira, L. Barros, Functional Food Ingredients from Plants, Vol. 90, $1^{\text {st }}$ Edition, ISBN: 9780128165676, (2018)

4. Y. H. Lee, C. Choo, M. Watawana, N. Jayawardena, V. Y. Waisundara, J. of the Sc. of Food and Agr., 95, 2956-2964, (2015)

5. N. Belc, L. Apostol, G. Vlasceanu, C. Mosoiu, T. Manasia, V. Vladut, S.A. Martinez, Romanian Biotech. Letters, 25, Issue 1, 1178-1185, (2020)

6. L. Apostol, N. Belc, L. Gaceu., V. Vladut, O.B. Oprea, Chemistry J., 70, Issue 6, 20482053, (2019)

7. C Popescu., C. Popescu (Popiniuc), Ş. Manea, O Calin., C. Morgovan, V. Vlăduţ, A. Dune, S. Ardelean, Annals of the Uni. of Craiova - Agr., Montanology, Cadastre, Series, 46, No. 2, 214-223, (2016)

8. S.F. Isticioaia, L. Apostol, G. Matei, O. Mîrzan, P. Pintilie, E. Trotuş, A. Leonte, V. Vladut, O. Cristea, B. Oprea, B. Furdui, C.M., Marinciu, M. Bularda, Romanian Agr. Res., 38, (2021)

9. O-M. Dumitru, S Iorga., N.V. Vladut, C. Bracacescu., INMATEH Agr. Eng. J., 62, No. $3,133-146,(2020)$ 
10. G. Matei, V. Vladut, S. Isticioaia, R.L. Panzaru, D. Popa, Scientific Papers-Series AAgronomy, 63, Issue 1, 387-393, (2020)

11. A. Kowalczyh-Jusko, K. Kupryaniuk, T. Oniszczuk, A. Wojtowicz, D., Janczak D., A. Smurzynska, K. Jozwiakowski, M. Czechlowski, Proceedings of the $3^{\text {rd }}$ Int. Conf. on Energy and Environment (ICEE 2017), 89-94, (2017)

12. V. Vlădut, S. Şt. Biriş, N. Ungureanu, I. Voicea, D. Cujbescu, L. Apostol, C. Moşoiu, S. Boruz, S. Isticioaia, Gh. Stroescu, A. Matache, D.N. Dumitru, Annals of the Uni. of Craiova - Agr., Montanology, Cadastre Series, 48, No. 2, 451-457, (2018)

13. Gh. Matei, V. Vlăduț, M. Ștefan, E Constantinescu., C. Sălceanu, Int. Symp. ISB-INMA TEH' 2018 Agr. and Mechanical Eng., 1041-1046, (2018)

14. R. Oprescu, S.Şt. Biriş, I. Voicea, V. Vlăduț, Acta Tech. Corviniesis - Bull. of Eng., Tome XII, Fascicule 1, 85-88, (2019), ISSN: 2067-3809

15. D. Popa, S. Isticioaia, G. Teliban, V. Vlăduţ, A. Nedelcu, Gh. Matei, O. Mîrzan, A. Panda, P. Pintilie, C. Melucă, A. Agapie, Sc. Papers, Horticulture Series, 63 (1), Agronomy series, 65-68, (2020)

16. L.D. Popa, S.F. Isticioaia, V. Vlăduț, G.C. Teliban, Gh. Matei, A. Leonte, A. Zaica, O. Cristea, Matache M., Int. Symp. ISB INMA TEH' 2020 Agr. and Mechanical Eng., 854$860,(2020)$

17. R. Oprescu, S.Şt. Biriş, I. Voicea, V. Vlăduț, Int. Symp. ISB-INMA TEH’ 2018, Agr. and Mechanical Eng., 325-330, (2018)

18. L-D. Popa, S. Isticioaia, V. Vlăduț, G. Teliban, G. Matei, A. Nedelcu, Int. Symp. ISBINMA TEH' Agr. and Mechanical Eng., 838-845, (2019)

19. F. Sîrbu, I. Dumitru, D. Iuga, I. Voicea, V. Vlăduţ, R. Oprescu, Acta Tech. Corviniensis - Bull. of Eng., Fascicule 2, 97-100, (2019)

20. V Vlăduţ., I. Găgeanu, L. Apostol, Gh. Matei, D. Popa, S. Isticioaia, N. Ungureanu, S.Şt. Biriş, T. Zelazinski, M. Epure, C. Dumitru, S.I. Biriş, Int. Symp. ISB-INMA TEH” Agr. and Mechanical Eng., 958-965, (2019)

21. V. Vlăduţ, A.I. Grigore, I Găgeanu., M. Neagoe, N. Vanghele, L. Apostol, Gh. Matei, D. Popa, S. Isticioaia, N. Ungureanu, S.Şt. Biriş, G Paraschiv., M. Epure, C. Dumitru, S.I. Biriş, Int. Symp. ISB-INMA TEH' 2019 Agr. and Mechanical Eng., 952-957, (2019)

22. A-G Burnete, A-M Lazăr, M. Catană, L. Catană, G. Stamatie, R.I. Teodorescu, N. Belc, V. Vlădut,, Int. Symp. ISB-INMA TEH' 2019 Agr. and Mechanical Eng., 817$825,(2019)$ 